\title{
RESIDENTS' SATISFACTION TOWARDS TOURISM EVENTS: A STUDY OF MUSIC FESTIVAL LOVEFEST, VRNJAČKA BANJA
}

\author{
Podovac Milena ${ }^{1}$ \\ Milićević Snežana ${ }^{2}$ \\ Đorđević Nataša ${ }^{3}$
}

\begin{abstract}
Electronic music festivals have become events that gather a large number of visitors, and they might represent one of the great motives for young people to visit a destination. As they may be a way of creating tourism growth, then residents' satisfaction and attitudes towards such festivals, must be considered in order to reach sustainable tourism development. This paper presents the results of a survey of the level of residents' satisfaction with the international electronic music festival Lovefest in Vrnjacka Banja. Also, it was examined if there are statistically significant differences in the level of residents' satisfaction depending on their socio-demographic characteristics and whether their jobs are tourism-related. The research sample included 480 respondents, i.e. residents of Vrnjačka Banja. The results of the research showed that there are statistically significant differences in the level of satisfaction with the Lovefest between the residents of different education.
\end{abstract}

\footnotetext{
1 University of Kragujevac, Faculty of Hotel Management and Tourism in Vrnjačka Banja, Vojvođanska 5A; 36210 Vrnjačka Banja: e-mail: milena.podovac@kg.ac.rs

2 University of Kragujevac, Faculty of Hotel Management and Tourism in Vrnjačka Banja, Vojvođanska 5A; 36210 Vrnjačka Banja: e-mail: snezana.milicevic@kg.ac.rs

3 University of Kragujevac, Faculty of Hotel Management and Tourism in Vrnjačka Banja, Vojvođanska 5A; 36210 Vrnjačka Banja: e-mail: natasa.djordjevic
} 
Keywords: Lovefest, electronic music festival, residents' satisfaction, Vrnjačka Banja.

\section{INTRODUCTION}

Music festivals are one of the most popular forms of entertainment today, especially large festivals, hosts of the biggest performers in international music charts, with thousands of fans, where the sound combined with spectacular visual effects and impressive settings create a unique sensorial experience (Cianga, 2020). Festivals are considered a significant part of event tourism, quite important for tourism development (Yozukmaz et al., 2020) as they can attract tourists, increase employment and make a destination more popular (NovakovićJojić \& Mandarić, 2019). Festivals are viewed as viable means of economic development (Felsenstein \& Fleischer, 2003), especially in small communities, where the town may welcome largest number of visitors (and the corresponding tourist expenditures) throughout the year in a few short weekends when event occurs (Woosnam \& Aleshinloye, 2018). Also, researches about the impacts of tourism festivals have primarily focused on economic impacts (Getz, 2010; Mair \& Whitford, 2013), while less emphasis is on their social impacts (Aleshinloye, 2015). The involvement of the residents and their favorable perceptions towards the events influence their attitudes and support of the event development (Negruşa et al., 2016). Residents' satisfaction with local festivals is also important, in order to measure their success and continued relevance (Ramkissoon, 2014), also because satisfying experiences can predict future intentions (Lee et al., 2012). The aim of this paper is to analyze the satisfaction of residents of Vrnjačka Banja, with international electronic music festival Lovefest (hereinafter referred to as Lovefest) depending on their socio-demographic characteristics (gender, age, education, professional status, location, and length of residence in the municipality of Vrnjačka Banja) and whether their jobs are tourism-related.

Lovefest is organized in the most visited spa destination in Serbia Vrnjačka Banja. This open air festival has been held for many years in August in the park near Jezero mineral spring on several stages where visitors can hear mostly electronic music, rock, and hip-hop music 
performed by musicians from all over the world. It attracts a predominantly younger population mostly from Serbia, Europe, but also from other countries of the world. Besides hotels and other forms of accommodation, visitors have the opportunity to choose an outdoor camp in the park of Vrnjačka Banja. It has tendencies to grow considering the fact that when the first time it was held in 2007 it gathered around 3,000 visitors and lasted for 2 days (Vrnjačka Banja, 2020) and from 2010 it lasts for 3 days while the average daily number of visitors is 20.000 (Lovefest, 2020). This is positive for the tourism economy of Vrnjačka Banja, primarily for tourism companies, like a higher occupancy rate of accommodation capacities, tourist consumption, etc. On the other side noise, crowds in destination (on the streets, in the shops, in the center of the Vrnjačka Banja, especially in the park where outdoors camp and stages are), traffic jams, lack of parking spaces may disturb the life of the local community, the experience of tourists who come primarily for health treatments, and may damage natural and cultural values and resources of destination. It is important to emphasize that the total population of the Vrnjačka Banja municipality is 27,527 (Statistical Office of the Republic of Serbia, 2020). Therefore, considering that Vrnjačka Banja is a small spa destination, with a long tradition of health tourism offer, and having in mind the positive and negative impact of international electronic music festivals, Lovefest is chosen to be subject of this study.

\section{LITERATURE REVIEW}

Tourism impacts on the host community form one of the most important research areas in the tourism literature (Xiao et al., 2006). A review of the tourism literature shows that tourism development affects residents' attitudes to tourism and tourism activities in a destination (Nunkoo, 2013; Rivera et al., 2016). Tourism can influence the economic, environmental, and sociocultural change in local communities, above all on residents' behaviors, lifestyles, and quality of life (Jaafar et al., 2017). Many studies have found that tourism development may have positive and negative impacts on the residents' quality of life, which can influence their attitudes toward tourism development and tourists ( $\mathrm{Su}$ et al., 2018). Today, tourism has the widest and most numerous system of connections with all spheres of economic and social life (Ubavić, 2015). 
Tourism can positively impact residents' quality of life by improving employment opportunities (Tomić et al., 2020), living standards, and destinations infrastructure; increasing the availability of sport-recreation and entertainment facilities; and preserving local culture, all buttressed by the economic bounty derived from the increased number of tourists (Deery et al., 2012; Milićević et al., 2020).

The results of survey which was conducted by Woo et al. (2018) states that the residents' attitudes of tourism impact and their life satisfaction are dependent on whether the residents are affiliated or not affiliated with the tourism sector. According to Jurowski et al. (1997), residents who anticipate greater economic gain or are dependent on the tourism industry tend to have a more positive attitude toward tourism and to incline to support tourism initiatives aimed at increasing number of tourists, compared to other residents. In other words, the more residents economically benefit from tourism, the more they support tourism (Boley et al., 2018). Among numerous studies on the various types of tourism impacts, researches focusing on tourism events' and festivals' impacts seem to have attracted particular attention (Zhou \& Ap, 2009; Weaver \& Lawton, 2013; Li et al., 2015). The study of Jackson (2008) indicates that residents are generally in favor of events that contribute socially and economically to the destination. They are, however, not ambivalent to some of the negative impacts, but are willing to cope with these negative impacts as long as the perceived benefits exceed the negative impacts. Research about the impacts of events and festivals on residents' well-being revealed that community benefits and cultural/educational benefits are positive predictors of subjective wellbeing of residents (Yolal et al., 2016). According to Düşmezkalender et al. (2019) perceived positive socioeconomic impacts of festival simultaneously increase the residents' willingness to revisit the festival.

Oftentimes, residents will assess impacts based on their personal background whether it is from previous festival participation, travel, or socio-demographic and socioeconomic classification (Woosnam et al., 2013). In that sense, Fredline and Faulkner (2002) found that residents who participated in the observed event had the most positive perceptions of impacts. The study about the residents' perceptions of the impacts of a festival in South Africa revealed more significant differences in terms of festival behavior (number of times attended and level of 
interest in the festival) than socio-demographic variables (gender, qualification, and occupation) of residents (Slabbert \& Viviers, 2012). When it comes to residents' satisfaction with festivals, the results of Mensah's study (2013) showed that residents with high involvement in the festival indicated higher satisfaction levels and were more likely to participate in the future than residents with low involvement were. However, gender was not a significant determinant of overall satisfaction with the festival. According to Chang et al. (2014), both, residents and tourists who were more involved with the festival had higher satisfaction levels. However, only residents who were highly satisfied with the festival were more likely to attend again, whereas tourists' satisfaction level did not significantly influence their likelihood of returning.

\section{RESEARCH METHODOLOGY}

The purpose of this paper is to examine the residents' satisfaction with the electronic music festival Lovefest in Vrnjačka Banja. As mentioned, the paper also analyzes statistically significant differences in the level of residents' satisfaction depending on their socio-demographic characteristics and whether their job is tourism-related. The following research questions were defined in the paper:

- Are the residents satisfied with the Lovefest?

- Are there a statistically significant differences in the level of the residents' satisfaction with the Lovefest depending on their sociodemographic characteristics (gender, age, level of education, professional status, place and length of residence in Vrnjačka Banja municipality) and depending on the connection of their job with tourism?

For the purpose of the research, a questionnaire was prepared, whereby available scientific studies with the same or similar research subject were previously analyzed (Tepavčević et al., 2019; Milićević et al., 2020; Pivac $t$ al., 2020). The questionnaire contains 8 questions, which are divided into two parts. The first part of the questionnaire contains 4 questions, which are related to the basic socio-demographic characteristics of the respondents. In the second part of the questionnaire, questions were asked about the place and length of residence of the respondents on the territory of the Vrnjačka Banja 
municipality. Also in this part of the questionnaire, respondents were asked questions about the connection of their job with tourism and the level of their satisfaction with the Lovefest. When they asked about the level of their satisfaction with the Lovefest, respondents answered this question using a five-point Likert scale (from 1= Completely dissatisfied to $5=$ Completely satisfied). The survey was conducted in August 2019 by sending a questionnaire to the e-mail addresses of potential respondents. As part of this survey, the respondents were asked a question of an elimination character, which referred to whether they live on the territory of the Vrnjačka Banja municipality. By analyzing the respondents' answers to this question, it was determined that the research sample includes 480 residents. For the purpose of the processing of collected data, statistical techniques and methods were applied. The collected data were processed in the statistical package SPSS 26. Descriptive statistical analysis, t-test of independent samples and one-factor analysis of variance (ANOVA) were used to process the collected responses of the respondents.

\section{RESEARCH RESULTS}

\section{Description of the Sample}

In this research, 480 respondents participated, of which $63.5 \%$ are female and $36.5 \%$ are male. Respondents aged 20-30 years have the highest participation in the sample $(40.4 \%)$. The largest number of respondents belongs to the category of respondents that have a bachelor's degree (35.2\%). Out of the total number of respondents, $73.1 \%$ stated that they are employed (Table 1 ). 
Table 1. Socio-demographic characteristics of the respondents $(n=480)$

\begin{tabular}{|c|c|c|c|c|}
\hline Variable & $\mathbf{n}$ & $\%$ & Mean & \begin{tabular}{|l|} 
Standard \\
deviation
\end{tabular} \\
\hline Gender & & & \multirow{3}{*}{1.64} & \multirow{3}{*}{482} \\
\hline Male & 175 & 36.5 & & \\
\hline Female & 305 & 63.5 & & \\
\hline Age & & & \multirow{6}{*}{1.96} & \multirow{6}{*}{1.022} \\
\hline $20-30$ & 194 & 40.4 & & \\
\hline $31-40$ & 162 & 33.8 & & \\
\hline $41-50$ & 83 & 17.3 & & \\
\hline $51-60$ & 29 & 6.0 & & \\
\hline$>60$ & 12 & 2.5 & & \\
\hline Level of education & & & \multirow{6}{*}{2.58} & \multirow{6}{*}{1.149} \\
\hline High school graduate & 125 & 26.0 & & \\
\hline Vocational degree & 73 & 15.2 & & \\
\hline Bachelor's degree & 169 & 35.2 & & \\
\hline Master's degree & 103 & 21.5 & & \\
\hline PhD degree & 10 & 2.1 & & \\
\hline Professional status & & & & \\
\hline Employed & 351 & 73.1 & \multirow{4}{*}{1.44} & \multirow{4}{*}{.805} \\
\hline Unemployed & 57 & 11.9 & & \\
\hline Student & 60 & 12.5 & & \\
\hline Retired & 12 & 2.5 & & \\
\hline Total & 480 & 100,0 & & \\
\hline
\end{tabular}

Source: Author's calculation based on SPSS 26.0

Table 2 shows the answers about the place and length of residence of the respondents in the Vrnjačka Banja municipality, the connection of their job with tourism, and the level of their satisfaction with the Lovefest. The majority of respondents stated that they live near the centre of Vrnjačka Banja (55.4\%). When they asked about the length of residence in Vrnjačka Banja, $29.2 \%$ of respondents stated that they have been living in the territory of this municipality between 20 and 30 years. When asked whether the work they do is related to tourism, the largest number of respondents $(66.3 \%)$ gave a positive answer. Of the total number of respondents, $28.7 \%$ stated that they were completely satisfied with this festival in Vrnjačka Banja, while $24.8 \%$ of respondents were satisfied 
(Table 2). The results of the descriptive statistical analysis proved that the residents are satisfied with the Lovefest.

Table 2. Descriptive statistical analysis of residents' responses $(n=480)$

\begin{tabular}{|c|c|c|c|c|}
\hline Variable & $\mathbf{n}$ & $\%$ & Mean & $\begin{array}{l}\text { Standard } \\
\text { deviation }\end{array}$ \\
\hline $\begin{array}{l}\text { Place of residence in Vrnjačka } \\
\text { Banja municipality }\end{array}$ & & & \multirow{5}{*}{2.21} & \multirow{5}{*}{.850} \\
\hline In the centre of municipality & 82 & 17.1 & & \\
\hline Near the centre of municipality & 266 & 55.4 & & \\
\hline On the outskirts of the municipality & 81 & 16.9 & & \\
\hline $\begin{array}{l}\text { In the surrounding village } \\
\text { municipality }\end{array}$ & 51 & 10.6 & & \\
\hline \multicolumn{3}{|l|}{$\begin{array}{l}\text { The length of residence in } \\
\text { Vrnjačka Banja }\end{array}$} & \multirow{7}{*}{3.95} & \multirow{7}{*}{1.529} \\
\hline up to 5 years & 56 & 11.7 & & \\
\hline $5-10$ & 34 & 7.1 & & \\
\hline $10-20$ & 58 & 12.1 & & \\
\hline $20-30$ & 140 & 29.2 & & \\
\hline $30-40$ & 115 & 24.0 & & \\
\hline$>40$ years & 77 & 16.0 & & \\
\hline \multicolumn{3}{|l|}{$\begin{array}{c}\text { The connection of their job with } \\
\text { tourism }\end{array}$} & \multirow{3}{*}{1.34} & \multirow{3}{*}{.473} \\
\hline Yes & 318 & 66.3 & & \\
\hline No & 162 & 33.8 & & \\
\hline \multicolumn{5}{|l|}{$\begin{array}{l}\text { The level of respondents' } \\
\text { satisfaction with the Lovefest }\end{array}$} \\
\hline Completely dissatisfied & 95 & 19.8 & \multirow{5}{*}{3.30} & \multirow{5}{*}{1.495} \\
\hline Dissatisfied & 62 & 12.9 & & \\
\hline Have no opinion on that & 66 & 13.8 & & \\
\hline Satisfied & 119 & 24.8 & & \\
\hline Completely satisfied & 138 & 28.7 & & \\
\hline Total & 480 & 100,0 & & \\
\hline
\end{tabular}

Source: Author's calculation based on SPSS 26.0 


\section{RESULTS OF THE T-TEST OF INDEPENDENT SAMPLES AND DISCUSSION}

An independent sample t-test was applied in order to compare the values of the arithmetic mean responses between male and female respondents about the level of their satisfaction with the Lovefest. The results of applied statistical analysis showed the level of significance, which is $p=.745$ higher than the limit value of 0.05 because of which we can conclude that there are no statistically significant differences in the level of satisfaction between male and female respondents with the Lovefest (Table 3).

Table 3. Results of the t-test of independent samples according to the gender of respondents

\begin{tabular}{|c|c|c|c|c|}
\hline \multirow{2}{*}{ Factor } & \multicolumn{2}{|c|}{ Gender } & \multirow{2}{*}{ t } & \multirow{2}{*}{ p } \\
\cline { 2 - 3 } & Male & Female & & \\
\hline $\begin{array}{c}\text { Level of respondents' } \\
\text { satisfaction with the Lovefest }\end{array}$ & $\mathrm{N}=175$ & $\mathrm{~N}=305$ & \multirow{2}{*}{-.325} & \multirow{2}{*}{.745} \\
\cline { 2 - 3 } & 3.27 & 3.31 & & \\
\hline
\end{tabular}

Source: Author's calculation based on SPSS 26.0

The t-test of independent samples was also used to examine the existence of a higher level of satisfaction with the Lovefest among respondents whose job is connected with tourism. The results of the t-test of independent samples showed a significance level of $p=.478$, which is higher than the limit value of 0.05 . These results indicated that the respondents whose job is related to tourism do not show a higher level of satisfaction with the Lovefest than those whose job is not related to tourism (Table 4).

Table 4. Results of the t-test of independent samples according to the connection between the job of respondents and tourism

\begin{tabular}{|c|c|c|c|c|}
\hline \multirow[t]{2}{*}{ Factor } & \multicolumn{2}{|c|}{$\begin{array}{l}\text { The connection between the } \\
\text { job of respondents and tourism }\end{array}$} & \multirow[t]{2}{*}{$\mathbf{t}$} & \multirow[t]{2}{*}{$\mathbf{p}$} \\
\hline & Yes & No & & \\
\hline \multirow{2}{*}{$\begin{array}{c}\text { Level of respondents' } \\
\text { satisfaction with the } \\
\text { Lovefest }\end{array}$} & $\mathrm{N}=318$ & $\mathrm{~N}=162$ & \multirow[b]{2}{*}{1.245} & \multirow[b]{2}{*}{478} \\
\hline & 3.36 & 3.18 & & \\
\hline
\end{tabular}

Source: Author's calculation based on SPSS 26.0 


\section{RESULTS OF ANOVA AND DISCUSSION}

ANOVA was used to examine the existence of the influence of the sociodemographic characteristics of the respondents on the level of their satisfaction with the Lovefest. The level of respondents' satisfaction with the Lovefest is defined as a dependent variable, while the independent variables are: age, level of education, professional status, place, and length of residence in the Vrnjačka Banja municipality.

Table 5. Results of ANOVA according to the age of respondents

\begin{tabular}{|c|c|c|c|c|c|c|c|}
\hline \multirow[b]{2}{*}{ Factor } & \multicolumn{5}{|c|}{ Middle value } & \multirow[b]{2}{*}{$\mathbf{F}$} & \multirow[b]{2}{*}{$\mathbf{p}$} \\
\hline & \begin{tabular}{|l|} 
group 1 \\
$(20-30)$
\end{tabular} & $\begin{array}{l}\text { group } 2 \\
(31-40)\end{array}$ & \begin{tabular}{|l|} 
group 3 \\
$(41-50)$
\end{tabular} & \begin{tabular}{|l|} 
group 4 \\
$(51-60)$
\end{tabular} & $\begin{array}{c}\text { group } 5 \\
(>60)\end{array}$ & & \\
\hline \begin{tabular}{|c} 
Level of \\
respondents' \\
satisfaction \\
with the \\
Lovefest
\end{tabular} & 3.25 & 3.43 & 3.18 & 3.41 & 2.83 & .801 & .525 \\
\hline
\end{tabular}

Source: Author's calculation based on SPSS 26.0

By applying ANOVA, it was examined the existence of statistically significant differences in the level of satisfaction of respondents of different ages with the Lovefest. Since the level of significance, which is $\mathrm{p}=.525$, is higher than the limit value of 0.05 , it was found that there are no statistically significant differences in the level of satisfaction of respondents of different ages with the Lovefest (Table 5). 
Table 6. Results of ANOVA according to the education of respondents

\begin{tabular}{|c|c|c|c|c|c|c|c|}
\hline \multirow[b]{2}{*}{ Factor } & \multicolumn{5}{|c|}{ Middle value } & \multirow[b]{2}{*}{$\mathbf{F}$} & \multirow[b]{2}{*}{$\mathbf{p}$} \\
\hline & 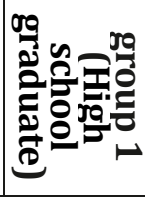 & 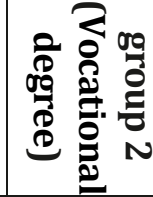 & 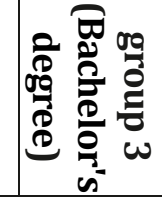 & 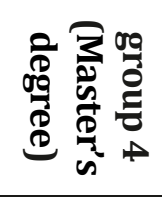 & 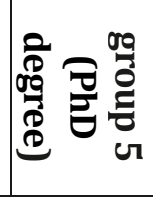 & & \\
\hline 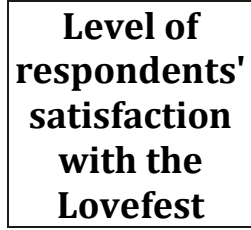 & 3.70 & 3.01 & 3.20 & 3.21 & 3.00 & 3.319 & $.011^{*}$ \\
\hline
\end{tabular}

${ }^{*} p<0.05$ Source: Author's calculation based on SPSS 26.0

The level of significance, whose value of .011 is less than the limit value of 0.05 , indicates the existence of statistically significant differences in the level of satisfaction of the respondents with different education with the Lovefest. Tukey post-hoc test was used in order to determined among which groups do exist statistically significant differences. The results of the mentioned test showed that there are statistically significant differences between respondents who graduated at the high school and those who have a vocational degree $(p=.016)$ as well as between respondents who have bachelor's degree and respondents who are high school graduates $(\mathrm{p}=.035)$ (Table 6). In the case of professional status, the results of ANOVA showed that this variable does not influence the level of respondents' satisfaction with the Lovefest because the significance level of .810 is higher than the limit value of 0.05 . (Table 7).

Table 7. Results of ANOVA according to the professional status of respondents

\begin{tabular}{|c|c|c|c|c|c|c|}
\hline \multirow[b]{2}{*}{ Factor } & \multicolumn{4}{|c|}{ Middle value } & \multirow[b]{2}{*}{$\mathbf{F}$} & \multirow[b]{2}{*}{$\mathbf{p}$} \\
\hline & $\begin{array}{c}\text { group 1 } \\
\text { (Employed) }\end{array}$ & $\begin{array}{c}\text { group } 2 \\
\text { (Unemployed) }\end{array}$ & $\begin{array}{c}\text { group } 3 \\
\text { (Student) }\end{array}$ & $\begin{array}{c}\text { group } 4 \\
\text { (Retired) }\end{array}$ & & \\
\hline \begin{tabular}{|c|} 
Level of \\
respondents' \\
satisfaction \\
the Lovefest
\end{tabular} & 3.30 & 3.18 & 3.43 & 3.17 & .321 & .810 \\
\hline
\end{tabular}

Source: Author's calculation based on SPSS 26.0 
It was determined that the place of the respondents' residence on the territory of Vrnjačka Banja municipality does not affect the level of their satisfaction with the Lovefest, because the level of significance is .687 higher than the limit value of 0.05 (Table 8).

Table 8. Results of ANOVA according to the place of residence in the Vrnjačka Banja municipality

\begin{tabular}{|c|c|c|c|c|c|c|}
\hline \multirow[b]{2}{*}{ Factor } & \multicolumn{4}{|c|}{ Middle value } & \multirow[b]{2}{*}{$\mathbf{F}$} & \multirow[b]{2}{*}{$\mathbf{p}$} \\
\hline & 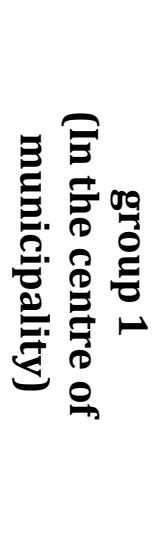 & 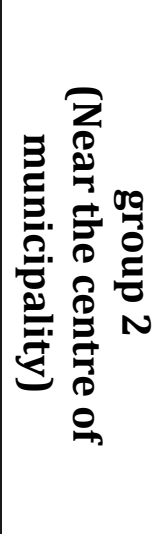 & 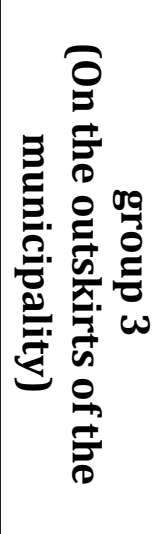 & 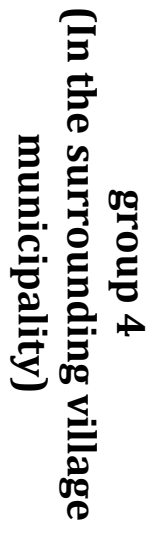 & & \\
\hline $\begin{array}{c}\text { Level of } \\
\text { respondents' } \\
\text { satisfaction } \\
\text { with the } \\
\text { Lovefest }\end{array}$ & 3.30 & 3.23 & 3.44 & 3.39 & .493 & .687 \\
\hline
\end{tabular}

Source: Author's calculation based on SPSS 26.0

Bearing in mind that the value of $\mathrm{p}=.932$ is higher than the limit value of 0.05 , it was determined that the length of residence of respondents in the municipality of Vrnjačka Banja does not influence the level of their satisfaction with the Lovefest (Table 9). 
Table 9. Results of ANOVA according to the length of residence in Vrnjačka Banja municipality

\begin{tabular}{|c|c|c|c|c|c|c|c|c|}
\hline \multirow[b]{2}{*}{ Factor } & \multicolumn{6}{|c|}{ Middle value } & \multirow[b]{2}{*}{$\mathbf{F}$} & \multirow[b]{2}{*}{$\mathbf{p}$} \\
\hline & 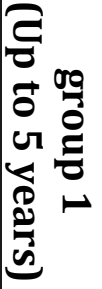 & 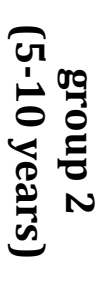 & 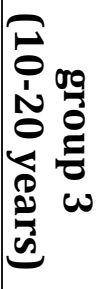 & 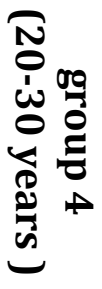 & 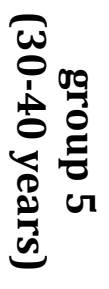 & 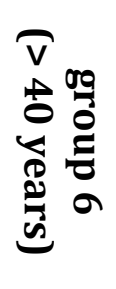 & & \\
\hline $\begin{array}{c}\text { Level of } \\
\text { respondents' } \\
\text { satisfaction of } \\
\text { with the Lovefest }\end{array}$ & 3.25 & 3.06 & 3.33 & 3.31 & 3.30 & 3.40 & .265 & .932 \\
\hline
\end{tabular}

Source: Author's calculation based on SPSS 26.0

\section{DISCUSSION}

There are numerous empirical studies about the impacts of tourism development on the local community (Uysal et al., 2016; Mendes et al., 2017) and about the impacts that tourism has on the quality of residents' lives (Usher \& Kerstetter, 2014; Podovac et al., 2019). Despite a large number of studies on this topic, the aspect of residents' satisfaction with the events in spa destinations is still insufficiently examined. This topic is partially covered by the authors of this study on the example of Vrnjačka Banja as the most important spa destination in the Serbia, where the electronic music festival Lovefest is organized every year. Based on research results obtained in this study, it can be concluded that gender, age, professional status, location, and length of residence in the Vrnjačka Banja municipality, and the connection between their job and tourism does not influence the level of residents' satisfaction with the Lovefest. Contrary to the expectations of the authors, this study revealed that gender was not a significant determinant of residents' satisfaction with the Lovefest which is also determined in the study of Mensah (2013). While Foroni et al. (2019) find out that unemployed and retired residents showed greater levels of satisfaction with tourism development, this study revealed that professional status does not determine the residents 
satisfaction with Lovefest. Although it has been confirmed in certain researches that residents who work in tourism or their job is related to tourism, express a higher level of satisfaction due to the holding of the event (Woo et al., 2018; Boley et al., 2018), in this paper, this statement is not confirmed.

Only regarding residents' education, there is a statistically significant difference in overall satisfaction with the Lovefest, more precisely between residents who are high school graduated and residents that have vocational's degrees, as well as between those with bachelor's degrees and respondents who are high school graduated. These results are consistent with the results obtained in the study of Mensah (2013) which research showed the existence of statistically significant differences in the overall satisfaction of the various educational levels of residents with the Asogli Yam Festival in Ghana. This author concluded that the respondents with basic education evaluated the festival highly than respondents without formal education, secondary and tertiary educational attainments. The results of the empirical study also showed that the place of the residents' residence on the territory of Vrnjačka Banja municipality does not influence the level of their satisfaction with the Lovefest which is consistent with some other studies (Jurowski \& Gursoy, 2004; Williams \& Lawson, 2001). Although the authors started from the assumption that the length of residence on the territory of the Vrnjačka Banja municipality affects the level of residents' satisfaction with the Lovefest, it has not been proven by the results of empirical research. Therefore, several other studies have shown the same results, i.e. that the amount of time spent living in someplace does not predispose residents to have positive attitudes and a high level of satisfaction (Allen et al., 1993; Andereck et al., 2005).

\section{CONCLUSION}

Bearing in mind that the residents represent a significant interest group in the tourism development, it is necessary to examine the level of their satisfaction with the defined policy of development of this economic activity. For the successful development of the entire tourism industry, but also of individual forms of tourism, it is very important to include residents in the process of decision making of tourism development in 
destination. Based on the results of empirical research, it was concluded that the residents of Vrnjačka Banja municipality are in most cases satisfied with this festival. This might be a precondition for their future support for the festival, nevertheless, future studies should focus on examining the relationship between residents`support for future festival development and their satisfaction with it. Examining the existence of statistically significant differences in the level of residents' satisfaction depending on their socio-demographic characteristics and whether their jobs are tourism-related, it was concluded that the level of education influence the residents' satisfaction with the Lovest. This study has certain limitations. The limitation is that only overall satisfaction with the festival is included. Therefore, it would be significant to investigate residents' satisfaction with particular elements of the festivals. The scientific contribution is reflected in the fact that there are only a few researches about residents'satisfaction with the festivals depending on its socio-demographic characteristics, and especially with festivals in spa destination. The practical contribution of the paper is reflected in the possibility of applying the research results in practice with the aim to achieve greater involvement of residents in planning and organization of the festival as well as for providing certain guidelines for improving festival management.

\section{REFERENCES}

1. Allen, R. L., Hafer, H. R., Long, P.T. \& Perdue, R. R. (1993). Rural residents' attitudes toward recreation and tourism development. Journal of Travel Research, 31(4), 27-33.

2. Aleshinloye, K. D. (2015). Examining Residents' and Tourists' Emotional Solidarity with One Another at the Osun-Osogbo Festival: A Modified Durkheimian Model (Doctoral dissertation).

3. Andereck, K. L., Valentine, K. M., Knopf, R. C. \& Vogt, C. A. (2005). Residents' perceptions of community tourism impacts. Annals of Tourism Research, 32(4), 1056-1076.

4. Boley, B. B., Strzelecka, M. \& Woosnam, K. M. (2018). Resident Perceptions of the Economic Benefits of Tourism: Toward a Common Measure. Journal of Hospitality \& Tourism Research, 42(8), 1295-1314. 
5. Chang, S., Gibson, H. \& Sisson, L. (2014). The loyalty process of residents and tourists in the festival context. Current Issues in Tourism, 17(9), 783-799.

6. Cianga, I. (2020). Festivals, Place-making and Local Economic Development: The Untold Festival in Cluj. Journal of Balkan and Near Eastern Studies, 1-15.

7. Deery, M., Jago, L. \& Fredline, L. (2012). Rethinking social impacts of tourism research: A new research agenda. Tourism Management, 33(1), 64-73.

8. Düşmezkalender, E., Özdemir, C. \& Yolal, M. (2019). A study on perceived socio-economic impacts of cultural festival on local residents participation: Kafkasör Culture Tourism and Art Festival. Turizm Akademik Dergisi, 6(1), 121-130.

9. Felsenstein, D., \& Fleischer, A. (2003). Local festivals and tourism promotion: The role of public assistance and visitor expenditure. Journal of Travel Research, 41, 385-392.

10. Foroni, I., Modica, P. \& Zenga, M. (2019). Residents' satisfaction with tourism and the European tourism indicator system in South Sardinia. Sustainability, 11(8), 2243.

11. Fredline, E., \& Faulkner, B. (2002). Variations in residents reactions to major motorsports events: Why residents perceive the impacts of events differently. Event Management, 7(2), 115-126.

12. Getz, D. (2010). The nature and scope of festival studies. International Journal of Event Management Research, 5(1), 1-47.

13. Jaafar, M., Rasoolimanesh, S. M. \& Ismail, S. (2017). Perceived sociocultural impacts of tourism and community participation: A case study of Langkawi Island. Tourism and Hospitality Research, 17(2), 123-134.

14. Jackson, L. A. (2008). Residents' perceptions of the impacts of special event tourism. Journal of Place Management and Development, 1(2), 240-255.

15. Jurowski, C., Uysal, M. \& Williams, D. R. (1997). A theoretical analysis of host community resident reactions to tourism. Journal of Travel Research, 36(2), 3-11.

16. Jurowski, C., \& Gursoy, D. (2004). Distance effects on residents' attitudes toward tourism. Annals of Tourism Research, 31(2), 296312. 
17. Lee, J., Kyle, G. \& Scott, D. (2012). The mediating effect of place attachment on the relationship between festival satisfaction and loyality to the festival hosting destination, Journal of Travel Research, 51(6), 754-767.

18. Li, X., Hsu, C. H. \& Lawton, L. J. (2015). Understanding residents' perception changes toward a mega-event through a dual-theory lens. Journal of Travel Research, 54(3), 396-410.

19. Lovefest (2020, December 20), Retrived from https://www.tickets.rs/ program/lovefest-2020-1735.

20. Mair, J., \& Whitford, M. (2013). An exploration of events research: Event topics, themes and emerging trends. International Journal of Event and Festival Management, 4(1), 6-30.

21. Mensah, C. (2013). Residents' satisfaction and behavioural intention with asogli Yam festival in Ghana. International Journal of Asian Social Science, 3(3), 682-702.

22. Mendes, R., Vareiro, L. \& Ferreira, A. R. (2017). Residents' perceptions of film-induced tourism: A Portuguese case study. Tourism and Hospitality Research, 17(4), 424-433.

23. Milićević, S., Podovac, M. \& Đorđević, N. (2020). Local residents' attitudes towards tourism events: A case study of the Carnival of Vrnjci, Serbia. Ekonomika, 66(2), 75-91.

24. Negruşa, A. L., Toader, V., Rus, R. V. \& Cosma, S. A. (2016). Study of perceptions on cultural events' sustainability. Sustainability, 8(12), 1269.

25. Novaković Jojić, Đ., \& Mandarić, M. (2019). Do events contribute to the brand of Novi Sad? A millennials' perspective. Hotel and Tourism Management, 7(1), 47-59.

26. Nunkoo, R., Smith, S. L. \& Ramkissoon, H. (2013). Residents' attitudes to tourism: A longitudinal study of 140 articles from 1984 to 2010. Journal of Sustainable Tourism, 21(1), 5-25.

27. Pivac, T., Blešić, I., Besermenji, S. \& Gavrilović, D. (2020). Attitudes of local population on the importance of events nourishing culture and tradition of Croats in Vojvodina. Turizam, 24(1), 46-56.

28. Podovac, M., Đorđević, N. \& Milićević, S. (2019). Rural tourism in the function of life quality improvement of rural population on Goč mountain. Economics of Agriculture, 66(1), 205-220.

29. Ramkissoon, H. (2014). Divali festival in Mauritius. In: Laing, J \& Frost, W. (Eds). Rituals and Traditional Events in the Modern World (pp. 39-50). New York: Routledge. 
30. Rivera, M., Croes, R. \& Lee, S. H. (2016). Tourism development and happiness: A residents' perspective.Journal of Destination Marketing \& Management, 5(1), 5-15.

31. Slabbert, E., \& Viviers, P. A. (2012). Residents' perceptions of the impacts of a major arts festival in South Africa. Tourism \& Management Studies, 1109-1113.

32. Statistical Office of the Republic of Serbia (2020, December 20). Census 2011. Retrieved from http://www.stat.gov.rs/enUS/oblasti/popis.

33. Su, L., Huang, S. \& Huang, J. (2018). Effects of destination social responsibility and tourism impacts on residents' support for tourism and perceived quality of life.Journal of Hospitality \& Tourism Research, 42(7), 1039-1057.

34. Tomić, S., Leković, K., Eskerod, P. \& Zedlacher, E. (2020). Profile of rural tourism consumers in Serbia and Austria. Anali Ekonomskog Fakulteta u Subotici, 56(44), 81-95.

35. Tepavčević, J., Blešić, I., Bradić, M. \& Ivkov, M. (2019). Attitudes of local residents towards tourism development in Vrbas. TIMS Acta, 13(1), 15-25.

36. Ubavić, P. (2015). Turistička politika i mogući pravci razvoja turizma u Srbiji. [Tourism policy and possible directions of tourism development in Serbia]. Ekonomija: teorija i praksa, 8(1), 16-31.

37. Usher, L. E., \& Kerstetter, D. (2014). Residents' perceptions of quality of life in a surf tourism destination: A case study of Las Salinas, Nicaragua. Progress in Development Studies, 14(4), 321333.

38. Uysal, M., Sirgy, M. J., Woo, E. \& Kim, H. L. (2016). Quality of life (QOL) and well-being research in tourism. Tourism Management, 53, 244-261.

39. Vrnjačka Banja. (2020, December 20). Retrived from https://evrnjackabanja.com/love-fest.

40. Weaver, D. B., \& Lawton, L. J. (2013). Resident Perceptions of a Contentious Tourism Event. Tourism Management, 37, 165-75.

41. Williams, J., \& Lawson, R. (2001). Community issues and resident opinions of tourism. Annals of Tourism Research, 28(2), 269-290.

42. Woo, E., Uysal, M. \& Sirgy, M. J. (2018). Tourism impact and stakeholders' quality of life. Journal of Hospitality \& Tourism Research, 42(2), 260-286. 
43. Woosnam, K. M., Van Winkle, C. M. \& An, S. (2013). Confirming the festival social impact attitude scale in the context of a rural Texas cultural festival. Event Management, 17(3), 257-270.

44. Woosnam, K. M., \& Aleshinloye, K. D. (2018). Residents' emotional solidarity with tourists: Explaining perceived impacts of a cultural heritage festival. Journal of Hospitality \& Tourism Research, 42(4), 587-605.

45. Xiao, H., \& Smith, S. L. J. (2006). The Making of Tourism Research: Insights from a Social Sciences Journal. Annals of Tourism Research, 33(2), 490-507.

46. Yolal, M., Gursoy, D., Uysal, M., Kim, H. L. \& Karacaoğlu, S. (2016). Impacts of festivals and events on residents' well-being. Annals of Tourism Research, 61, 1-18.

47. Yozukmaz, N., Bertan, S. \& Alkaya, S. (2020). Festivals' social impacts and emotional solidarity. International Journal of Event and Festival Management, 11(2), 239-253.

48. Zhou, Y., \& Ap, J. (2009). Residents' perceptions towards the impacts of the Beijing 2008 Olympic Games. Journal of Travel Research, 48(1), 78-91.

\section{ACKNOWLEDGEMENT}

Project no. III 46006 - Sustainable agriculture and rural development in the function of accomplishing strategic objectives of the Republic of Serbia in the Danube region, financed by the Ministry of Education, Science and Technological Development of the Republic of Serbia. Project period: 2011-2019. 


\title{
ZADOVOLJSTVO STANOVNIKA TURISTIČKIM DOGAĐAJIMA: STUDIJA MUZIČKOG FESTIVALA LOVEFEST, VRNJAČKA BANJA
}

\author{
Podovac Milena
}

Milićević Snežana

Đorđević Nataša

Sažetak: Festivali elektronske muzike su postali događaji koji okupljaju veliki broj posetilaca $i$ mogu predstavljati jedan od značajnih motiva mladih da posete određenu destinaciju. Kako oni mogu biti način za stvaranje turističkog rasta, neophodno je razmotriti zadovoljstvo $i$ odnos stanovnika prema takvim festivalima da bi se dostigao održivi razvoj turizma. U ovom radu prikazani su rezultati istraživanja zadovoljstva stanovnika opštine Vrnjačka Banja održavanjem međunarodnog festivala elektronske muzike Lovefest. Takođe je ispitano postojanje statistički značajnih razlika u stepenu zadovoljstva lokalnog stanovništva različitih socio-demografskih karakteristika, kao i u zavisnosti od povezanosti njihovog posla sa turizmom. Uzorak istraživanja obuhvatio je 480 ispitanika, odnosno stanovnika Vrnjačke Banje. Rezultati israživanja su pokazali da postoje statistički značajne razlike u stepenu zadovoljstva lokalnog stanovništva različitog obrazovanja povodom održavanja festivala elektronske muzike Lovefest.

Ključne reči: Lovefest, festival elektronske muzike, zadovoljstvo lokalnog stanovništva, Vrnjačka Banja. 